\title{
Quarterly Earnings Announcement Effect on Stock Return and Trading Volume in Nepal Jeetendra Dangol, $\mathrm{PhD}^{\star}$ and Ajay Bhandari**
}

\begin{abstract}
The study examines the stock returns and trading volume reaction to quarterly earnings announcements using the event analysis methodology. Ten commercial banks with 313 earnings announcements are considered between the fiscal year 2010/11 and 2017/18. The observations are portioned into 225 earning-increased (good-news) sub-samples and 88 earning-decreased (bad-news) sub-samples. This paper finds that the Nepalese stock market is inefficient at a semi-strong level, but there is a strong linkage between quarterly earnings announcement and trading volume. Similarly, the study provides evidence of existence of information content hypothesis in the Nepalese stock market.
\end{abstract}

Keywords: Efficient market hypothesis, earnings announcement, stock return, trading volume, event methodology

${ }^{\star}$ Associate Professor, Faculty of Management, Tribhuvan University, email: jdangol@gmail.com, ${ }^{* *}$ Freelance Researcher,email: ajaybhandari2468@gmail.com 


\section{Introduction}

According to Fama (1970, 1991), the Efficient Market Hypothesis (EMH) suggests that gaining from predicting price movements is very difficult and unlikely. The main factor behind the price changes is the arrival of new information. A market is said to be "efficient" if price adjusts quickly and correctly, and, on average, without bias, to new information. It indicates that the current prices of securities reflect all available information at any given point in time.

Organizations listed in Securities Exchange are required to communicate their financial performances to stakeholders through financial statements. Financial statements therefore act as an important tool for reviewing the organizations' performance because it allows investors to determine the direct impact on returns to investment (Kiremu, Galo, Wagala, \& Mutegi, 2013). Since publication of financial reports is public information, therefore it is expected that these information gets incorporated quickly and correctly into the stock prices as depicted by semi-strong form of efficient market.

Earnings announcements (EAs) result in investor reactions on two dimensions: price reactions and trading volume reactions. A growing body of literature asserts that the primary driver of trading volume reactions to public announcements is investor heterogeneity in the form of differential interpretation of the news (e.g., Beaver 1968; Harris \& Raviv 1993; Kandel \& Pearson 1995; Bamber et al. 1997, 1999; Bamber et al. 2011). In this context, the objective of the study is to examine effect of quarterly earnings announcement on stock returns and trading volume, i.e., testing the semi-strong form of market efficiency.

The next section reviews the literature on the subject. The methodology of the study are discussed in the third section. The fourth section presents the empirical results and the last section provides the conclusions.

\section{Literature Review}

Fama (1970) classified the market efficiency into three levels on the basis of the information. After twenty years of market efficiency literature published in 1970, Fama (1991) proposed to change the categories of market efficiency, namely:

1) Using tests for return predictability instead of weak-form tests, which are only concerned with forecast power of past returns, i.e., how well do past returns predict future returns?

2) Using event studies instead of semi-strong-form tests of the adjustment of prices to public announcements, i.e., how quickly do prices reflect public information announcements? 
3) Using test for private information instead of strong-form tests of whether specific investors have information in market prices or not, i.e., do any investors have private information that is not fully reflected in market prices?

The security market react information pertaining to earnings and found that the market was efficient (Ball \& Brown, 1968, Foster, 1977, Brown \& Han, 2000). It indicates that the investors cannot outperform the market based on publicly available information.

Even though the above studies supported the EMH in developed and developing economies, there were few studies which questioned its validity and found that the market was inefficient. Rendleman, Jones, and Henry (1982), Bernard and Thomas (1990), and Mendenhall (1991) argued that the stock markets fail to adjust quickly and correctly to new information flow and, therefore, investors are able to earn excess returns.

Ball and Kothari (1991) concluded that earnings announcement usually include information which was not available to the market and excess returns were generated on the announcement day. Olowe (2011) investigated stock price reaction in the Nigerian stock market and found that the stock market is inefficient. Mallikarjunappa and Dsouza (2013) found significant cumulative average abnormal return values after the earnings announcements. All these evidences demonstrated that earnings announcements contain information value which was not available to the market and the stock prices fail to reflect all the information released to the public.

Trading volume reflects the investors' activity by summing all market trades. In this regard, different approaches may be taken. Analysts may use the percentage of shares traded adjusted for the overall market level of trading as the expectation. Beaver (1968) used each firm's percentage of shares traded on an index of market-wide trading defined as the percentage of shares traded on an exchange. Since the amount of trading depends on the number of shares outstanding, the trading volume measures are based on the percentage of shares traded.

\section{Earnings announcement and Post earnings announcement drift (PEAD)}

This study was based on the premise that earnings announcements have information content, and therefore the release of such information will induce market reactions (How, Huang, \& Verhoeven, 2005). Post-earnings announcement drift (PEAD) refers to the predictable pattern whereby, after the announcement of quarterly earnings, equity prices continue to move in the same direction of the earnings surprise for a prolonged period. Abnormal returns that can be earned based on a PEAD trading strategy have been shown to be significant both economically and statistically, with the bulk concentrating around subsequent earnings announcements (Foster, Oslen, \& Terry, 1984); Bernard \& Thomas, 1989).

\section{Relationship between price and trading volume}

Trading volume reflects a lack of consensus regarding the price. Such lack of consensus 
is induced by new price information regarding the earnings report of a firm. If consensus were reached on the first transaction, there would be a price reaction but no volume reaction, assuming homogeneous risk preferences among investors. However, there should be a volume reaction even after the equilibrium price had been reached if risk preferences differ among the investors. Price reflects changes in the expectations of the market as a whole and the volume reflects changes in the expectations of individual investors. A piece of information may change the expectations of individuals rather than it changes the expectations of the market as a whole. Under these circumstances, there would be no price reaction but there would be shifts in portfolio positions reflected in the volume. Beaver (1968) argued that price reflects expectations of many investors. So, it may imply a very efficient forecast of earnings for several days prior to the announcement date. Rising trading volume is an increase in trading activity of investors in the market.

\section{METHODOLOGY}

\section{Data and Selection of Enterprises}

This study is based on secondary data, such as, daily share price, NEPSE index, and daily trading volumes. This information is collected from the official website of Nepal Stock Exchange. The earnings announcement data are collected from newspapers, online news portals.

As per the NEPSE trading reports, more than 80.23 per cent of the transactions were the securities of the commercial banks and financial institutions. It means that shares of commercial banks and financial institutions have ruled the roost of the investors' faith as well as the market itself. All the listed commercial banks with the Nepal Stock Exchange Limited have been considered as the total population of the study. The sample commercial banks of the study should fulfill the following criteria:

- Commercial banks which were never delisted even for a short period.

- Available financial and market information during the period 2010/11 to 2017/18.

- Commercial banks considered as a sample had announced earnings each quarter.

- Stocks with insufficient data points, either as a result of non-trading or lack of financial and market information as well as merger or acquisition will be excluded from the sample.

Commercial banks meeting these criteria were found 19 banks. Among of the 19 commercial banks, 5 highest and 5 lowest market capitalised banks were selected for analysis.

\section{Method of Analysis}

Event study methodology (Louhichi, 2008, Ariff \& Finn, 1989, Gajewski \& Quere 2001, Mushidzhi \& Ward, 2004, Kong \& Taghavi, 2006, Mallikarjunappa \& Dsouza, 2013) used 
for data analysis. The quarterly earnings of each bank were compared with the previous quarter earnings published in the daily newspaper and websites of concerned bank. This determined the nature of the information on the earnings announcement as either earnings increases or earnings decreases information.

The study used daily data to set the event window at five days before and five days after the earnings announcement day which is shown in figure 1 . This event window was used by Qureshi, Abdullah and Imdadullah (2012) to test the stock prices variability around earnings announcement date at Karachi Stock Exchnage. The announcement day represented by day zero ( 0$)$.

FIGURE 1: Event Periods
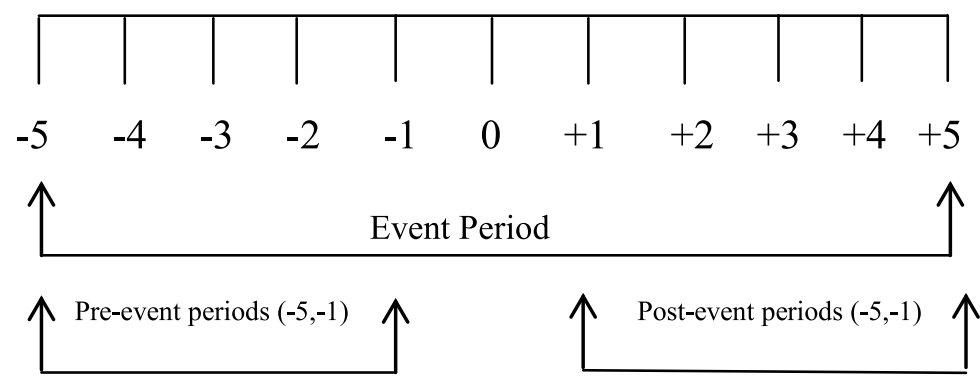

The abnormal returns and abnormal volumes of the commercial banks for the event window are calculated using market adjusted model that has been used in different studies by Mallikarjunappa and Dsouza (2013), Kakiya et al. (2013), and Maronga, Nyamosi, and Onsando (2015) which is shown in table 1.

TABLE 1: Model used to calculate abnormal return and abnormal volume

\begin{tabular}{|c|c|}
\hline Model used to calculate Abnormal Returns & $\begin{array}{l}\text { Model used to calculate Abnormal } \\
\text { Trading Volumes }\end{array}$ \\
\hline 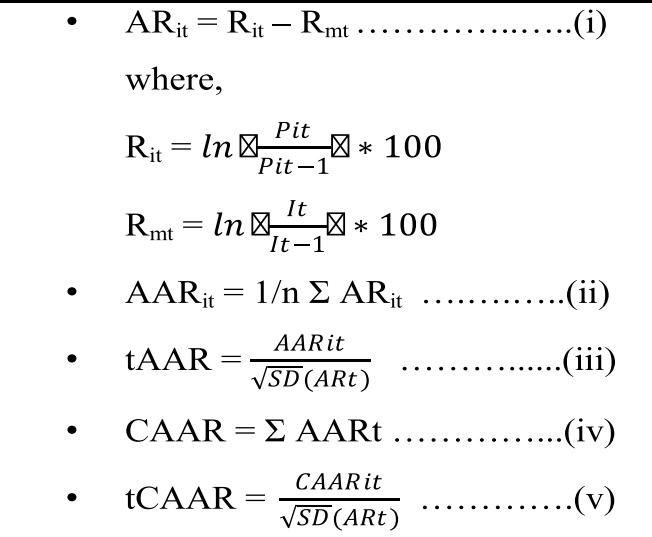 & 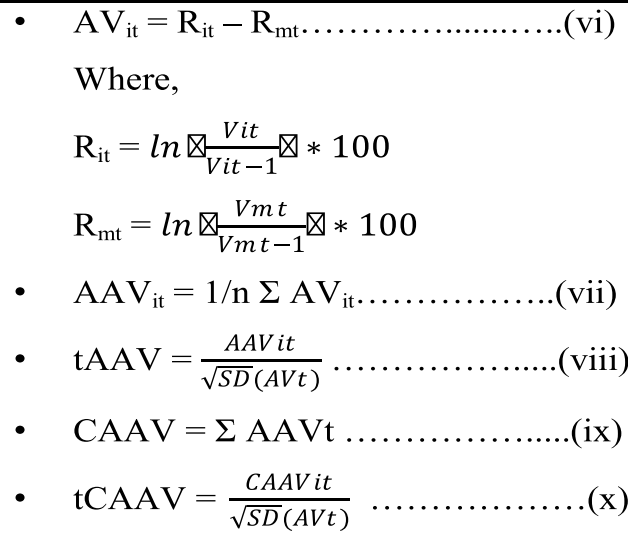 \\
\hline
\end{tabular}


Where, the it in returns represent security $i$ on trading day $t$ and in volume represent trading volume for security $i$ on trading day $t$. The Rit in return represent daily return for security $i$ on trading day and in volume represent percentage change on trading volume for security $i$ on trading day $t$. The Pit and Pit- 1 is the closing price of share $i$ on trading day $t$ and $t-1$, similarly, Vit and Vit-1 is the total traded volume of share $i$ on trading day $t$ and $t-1$. The $\operatorname{Ln}$ is the natural log and the reasons to take logarithm returns are justified by both theoretically and empirically (Dangol 2012).

The average market-adjusted excess return of $i$ security for event time $t$ is given by the equally weighted average of the individual stocks as in equation (ii) and the average marketadjusted excess volume in equation (vii). The AARs and AAVs are tested for statistical significance using the $t$-statistic as in equation (iii) and (viii). To make generalizations and to draw an overall conclusion for the market response to earnings announcements, the study analyzed cumulative average abnormal returns (CAARs) and cumulative average abnormal volumes (CAAVs) as shown in equation (iv) and (ix) on different varying event windows such as pre-event period of $(-5,-1)$, post-event period of $(+1,+5)$, overlapping period of $(-1,+1),(-3,+3)$ and overall period of $(-5,+5)$. The total CAARs and CAAVs are summed up to obtain the cumulative mean average abnormal returns and cumulative mean average abnormal volume and then test for statistical significance using a similar $\mathrm{t}$-statistic to the one adopted for testing the statistical significance of abnormal returns and abnormal volumes. The new t-statistic is calculated as in equation (v) for CAARs and equation ( $\mathrm{x}$ ) for CAAVs respectively.

Finally, the significance of daily average abnormal returns and average abnormal volumes are further tested using a non-parametric binominal statistic calculated as in equation (xi):

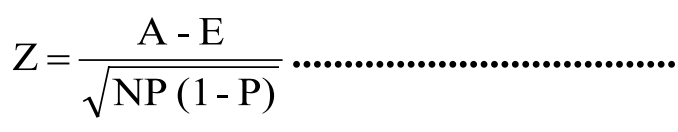

Where, $\mathrm{A}$ is actual number of positive abnormal returns and abnormal volumes, $\mathrm{E}$ is $\mathrm{N}$ multiply $\mathrm{P}, \mathrm{P}$ is the expected per cent of positive abnormal returns and abnormal volumes and $\mathrm{N}$ is the number of observations.

Where, $\mathrm{A}$ is actual number of positive abnormal returns and abnormal volumes, $\mathrm{E}$ is $\mathrm{N}$ multiply $\mathrm{P}, \mathrm{P}$ is the expected per cent of positive abnormal returns and abnormal volumes and $\mathrm{N}$ is the number of observations.

\section{Results}

Table 2 delineates the sample of earnings changes over the study period. There were in total 313 observations, which were partitioned into 225 observations in earnings-increase (good-news) category and 88 observations in earnings-decrease (bad-news) category. 
The earnings-increase announcements were bound to introduce substantial certainty about the future course of the firm business and the share market. It had enhanced the investors' confidence. Thus, a positive value-effect was expected from the earningsincrease announcements. Similarly, the earnings-decrease announcements were bound to introduce substantial uncertainty about the future course of the firm business and its returns, and therefore it results in loss of investors' confidence. Thus, a negative value effect was expected from the earnings-decrease announcements.

Table 2: Total Bank Observation, Earning-Increased (Good-News) and Earning-Decreased (Bad-News)

\begin{tabular}{cccc}
\hline Fiscal Year & Total & Earnings Increased & Earning Decreased \\
\hline & Observation & (Good-News) & (Bad-News) \\
\hline $2010 / 11$ & 40 & 25 & 15 \\
$2011 / 12$ & 40 & 26 & 14 \\
$2012 / 13$ & 39 & 28 & 11 \\
$2013 / 14$ & 40 & 30 & 10 \\
$2014 / 15$ & 38 & 29 & 9 \\
$2015 / 16$ & 39 & 30 & 9 \\
$2016 / 17$ & 37 & 27 & 10 \\
$2017 / 18$ & 40 & 30 & 10 \\
\hline Total & 313 & 225 & 88 \\
\hline
\end{tabular}

\section{Market reaction to earnings-increase (good-news) announcements}

Table 3 shows average daily abnormal returns in panel "A" and cumulative average abnormal returns in panel "B" for the good-news announcements with respect to earnings announcement. The good news announcements cause strong positive average abnormal returns, either daily or cumulatively.

The average abnormal return on the event announcement day $t=0$ is negative 0.06 per cent $(\mathrm{t}$-statistic $=-0.32$, not significant $)$. The highest positive abnormal return among the event window was 53.78 per cent on the day $\mathrm{t}=+2$ and $\mathrm{t}=+4$ where average abnormal return on $\mathrm{t}=+2$ is positive 0.16 per cent but not statistically significant and average abnormal return on day $\mathrm{t}=+4$ is positive 0.36 per cent which is the highest positive abnormal return on event window and statically significant at 1 per cent level with $\mathrm{t}$-statistics 2.40 . On day $\mathrm{t}=$ +1 , average abnormal return is negative 0.14 percent which is not statistically supported by parametric t-test. It shows the strong effect of good news announcements on stock prices. 
TABLE 3: Summary of average daily abnormal returns for the earning increased (good-news) over the period 2010/11 to 2017/18.

\begin{tabular}{ccccc}
\hline \multicolumn{5}{c}{ Panel A: Average Daily Abnormal Returns Earning Increased Sub-Sample } \\
\hline Day & $\begin{array}{c}\text { Average } \\
\text { Abnormal Returns }\end{array}$ & $\begin{array}{c}\text { t-statistics for Average } \\
\text { Abnormal Returns }\end{array}$ & $\begin{array}{c}\text { Z-Statistics for } \\
\text { Percentage Positive }\end{array}$ & $\begin{array}{c}\text { Percentage Positive } \\
\text { Abnormal Returns }\end{array}$ \\
\hline-5 & $0.06 \%$ & 0.52 & -1.00 & 46.67 \\
-4 & $-0.02 \%$ & -0.20 & -0.87 & 47.11 \\
-3 & $-0.05 \%$ & -0.41 & $-2.07^{* *}$ & 43.11 \\
-2 & $-0.28 \%$ & $-2.45^{* * *}$ & $-2.60^{* * *}$ & 41.33 \\
-1 & $0.03 \%$ & 0.28 & -1.27 & 45.78 \\
0 & $-0.06 \%$ & -0.32 & 0.73 & 52.44 \\
1 & $-0.14 \%$ & -1.04 & $-1.80^{*}$ & 44.00 \\
2 & $0.16 \%$ & 1.18 & 1.13 & 53.78 \\
3 & $0.06 \%$ & 0.43 & -1.13 & 46.22 \\
4 & $0.36 \%$ & $2.40^{* * *}$ & 1.13 & 53.78 \\
5 & $-0.10 \%$ & -0.74 & -1.27 & 45.78 \\
\hline
\end{tabular}

Panel B: Cumulative Average Abnormal Returns

\begin{tabular}{ccccc}
\hline Period & $\begin{array}{c}\text { Cumulative Average } \\
\text { Abnormal Returns }\end{array}$ & $\begin{array}{c}\text { t-Statistics for } \\
\text { Cumulative Average } \\
\text { Abnormal Returns }\end{array}$ & $\begin{array}{c}\text { Z-Statistics for } \\
\text { Percentage Positive }\end{array}$ & $\begin{array}{c}\text { Percentage Positive } \\
\text { Cumulative Abnormal } \\
\text { Returns }\end{array}$ \\
\hline$(-5,+5)$ & $0.01 \%$ & 0.04 & -1.13 & 46.22 \\
$(-5,-1)$ & $-0.24 \%$ & -1.12 & -1.40 & 45.33 \\
$(-1,+1)$ & $-0.41 \%$ & $-1.51^{*}$ & -1.13 & 46.22 \\
$(-3,+3)$ & $-0.69 \%$ & $-2.47^{* * *}$ & -1.53 & 44.89 \\
$(+1,+5)$ & $-0.36 \%$ & $-1.34^{*}$ & -0.07 & 49.78 \\
\hline
\end{tabular}

* $\quad$ Significant at the $10 \%$ level (two-tail test)

** Significant at the $5 \%$ level (two-tail test)

$* * * \quad$ Significant at the $1 \%$ level (two-tail test)

The cumulative average abnormal return is negative 0.24 per cent $(\mathrm{t}$-statistic $=-1.12$, not significant) on pre event period $(-5,-1)$. It had increased to the negative 0.36 per cent on the post event period $(+1,+5)$ which is statistically significant at 10 per cent level with $t$-statistics -1.34 and percentage of positive CAR is 49.78 per cent. It means that the good-news sub-samples appear to have the higher negative abnormal returns around the announcement event period. It is because of the short term under reaction to news which adjusts to the fundamentalvaluein thelongereventwindow. Thus, thegoodnewssub-sampleoftheearnings announcements has placed the negative valuation effects around the announcement period. Thus, this result implies that increase in earnings has not statistically significant impact on the dayofannouncement. However, both theparametrict-testandnon-parametricz-testshowed significant result on day $t=-2$, which possibly can be caused due to leakage of information. 


\section{Market reaction to earnings-decrease (bad-news) announcements}

Table 4 depicts average daily abnormal returns in panel "A" and cumulative average abnormal returns in panel "B" for the bad-news announcements with respect to earnings announcement. The bad-news announcements cause strong negative average abnormal returns, either daily or cumulatively.

TABLE 4: Summary of average daily abnormal returns for the earning decreased (badnews) over the period $2010 / 11$ to $2017 / 18$.

\begin{tabular}{|c|c|c|c|c|}
\hline \multicolumn{5}{|c|}{ Panel A: Average Daily Abnormal Returns Earning Decreased Sub-Sample } \\
\hline Day & $\begin{array}{l}\text { Average Abnormal } \\
\text { Returns }\end{array}$ & $\begin{array}{l}\text { t-statistics for Average } \\
\text { Abnormal Returns }\end{array}$ & $\begin{array}{c}\text { Z-Statistics for } \\
\text { Percentage Positive }\end{array}$ & $\begin{array}{c}\text { Percentage Positive } \\
\text { Abnormal Returns }\end{array}$ \\
\hline-5 & $-0.14 \%$ & -0.70 & -0.43 & 47.73 \\
\hline-4 & $-0.05 \%$ & -0.22 & 0.43 & 52.27 \\
\hline-3 & $-0.10 \%$ & -0.46 & 0.64 & 53.41 \\
\hline-2 & $-0.13 \%$ & -0.76 & -0.43 & 47.73 \\
\hline-1 & $0.26 \%$ & 1.28 & 1.07 & 55.68 \\
\hline 0 & $-0.31 \%$ & -1.17 & -1.07 & 44.32 \\
\hline 1 & $-0.60 \%$ & $-2.51 * * *$ & -1.28 & 43.18 \\
\hline 2 & $0.22 \%$ & 0.96 & 1.07 & 55.68 \\
\hline 3 & $-0.01 \%$ & -0.04 & 0.00 & 50.00 \\
\hline 4 & $0.13 \%$ & 0.64 & -0.64 & 46.59 \\
\hline 5 & $-0.08 \%$ & -0.32 & -0.64 & 46.59 \\
\hline
\end{tabular}

Panel B: Cumulative Average Abnormal Returns

\begin{tabular}{ccccc}
\hline Period & $\begin{array}{c}\text { Cumulative Average } \\
\text { Abnormal Returns }\end{array}$ & $\begin{array}{c}\text { t-Statistics for } \\
\text { Cumulative Average } \\
\text { Abnormal Returns }\end{array}$ & $\begin{array}{c}\text { Z-Statistics for } \\
\text { Percentage Positive }\end{array}$ & $\begin{array}{c}\text { Percentage Positive } \\
\text { Cumulative Abnormal } \\
\text { Returns }\end{array}$ \\
\hline$(-5,+5)$ & $-0.82 \%$ & -1.22 & $-2.56^{* *}$ & 36.36 \\
$(-5,-1)$ & $-0.99 \%$ & $-2.56^{* * *}$ & -0.85 & 45.45 \\
$(-1,+1)$ & $-1.64 \%$ & $-4.18^{* * *}$ & $-1.71^{*}$ & 40.91 \\
$(-3,+3)$ & $-2.33 \%$ & $-4.32^{* * *}$ & $-2.35^{* *}$ & 37.50 \\
$(+1,+5)$ & $-2.66 \%$ & $-6.11^{* * *}$ & -0.85 & 45.45 \\
\hline
\end{tabular}

* $\quad$ Significant at the $10 \%$ level (two-tail test)

** Significant at the $5 \%$ level (two-tail test)

$* * * \quad$ Significant at the $1 \%$ level (two-tail test)

The cumulative average abnormal return over the pre-announcement period $(-5,-1)$ was negative 0.99 per cent ( $\mathrm{t}$-statistic $=-2.56$, significant at 1 per cent level). Similarly, the negative CAAR in pre-event period is followed by negative CAAR during the overlapping period and post-event period. During post announcement period $(+1,+5)$, t-statistic of negative 6.11 is statistically significant at 1 percent level for CAAR negative 2.66 percent. 
About 45.45 percent of the sample firm observation had positive cumulative average abnormal return. Similarly, on overlapping period $(-1,+1)$ t statistic of negative 4.18 is statistically significant at 1 percent level for CAAR negative 1.64 percent. About 40.91 percent of the sample firm observations had positive average abnormal returns and it is statistically significant at 10 percent level (z-statistics $=-1.71)$. Therefore, investor reacts negatively during the post-announcement period and short overlapping period. During overlapping period $(-3,+3)$, negative cumulative average abnormal return is observed and it is statistically significant in both parametric t-test and non-parametric z-test. However, the shorter the overlapping period, lower the negative CAAR impact of bad news quarterly earnings announcements. It indicates that the negative cumulative average abnormal returns earned during the pre-event $(-5,-1)$ continues to be negative on the post-event period $(+1,+5)$. Hence, the negative valuation effect of earnings-decrease (bad-news) announcements on share market has been found.

Thus, the result implies that earnings decrease impact was seen statistically on days $t=+1$. It may be because of information after the event period had adjusted on day $t=+1$. Also, non-parametric test showed no significant impact of bad news on stock prices.

\section{Trading volume reaction to earnings-increase (good-news) announcements}

Table 5 shows average daily abnormal volumes in panel "A" and cumulative average abnormal volumes in panel " $\mathrm{B}$ " for the good-news announcements with respect to earnings announcement. The good-news announcements cause strong positive average abnormal volumes, either daily or cumulatively.

The $t$-statistics was strongly positive 3.50 per cent for the event day $t=0$, statistically significant at 1 percent level. The highest positive abnormal volumes among the event window were 27.26 per cent on the day of the earnings announcements. It indicates that the earnings announcement with the good-news has positive signal effect in the Nepalese stock market and it was statistically significant at the 1 percent level. It shows the strong effect of good news announcements on trading volumes.

TABLE 5: Summary of average daily abnormal trading volume for the good-news over the period 2010/11 to $2017 / 18$ :

Panel A: Average Daily Abnormal Volume Earning Increased Sub-Sample

\begin{tabular}{ccccc}
\hline Day & $\begin{array}{c}\text { Average Abnormal } \\
\text { Volume }\end{array}$ & $\begin{array}{c}\text { t-Statistics for Average } \\
\text { Abnormal Volume }\end{array}$ & $\begin{array}{c}\text { Z-Statistics for } \\
\text { Positive Percentage }\end{array}$ & $\begin{array}{c}\text { Percentage Positive } \\
\text { Abnormal Volume }\end{array}$ \\
\hline-5 & $-12.52 \%$ & $-1.57^{*}$ & $-1.67^{*}$ & 44.44 \\
-4 & $0.34 \%$ & 0.05 & -0.73 & 47.56 \\
-3 & $16.98 \%$ & $2.40^{* * *}$ & $2.20^{* *}$ & 57.33 \\
-2 & $-17.50 \%$ & $-2.37^{* *}$ & -0.33 & 48.89 \\
-1 & $6.92 \%$ & 0.96 & 0.47 & 51.56
\end{tabular}




\begin{tabular}{ccccc}
0 & $27.26 \%$ & $3.50^{* * *}$ & $2.87^{* * *}$ & 59.56 \\
1 & $-12.82 \%$ & $-1.42^{*}$ & $-3.53^{* * *}$ & 38.22 \\
2 & $-2.44 \%$ & -0.36 & -1.13 & 46.22 \\
3 & $-4.73 \%$ & -0.70 & -0.60 & 48.00 \\
4 & $0.14 \%$ & 0.02 & -0.87 & 47.11 \\
5 & $3.86 \%$ & 0.52 & -0.07 & 49.78 \\
\hline
\end{tabular}

Panel B: Cumulative Average Abnormal Volume

\begin{tabular}{ccccc}
\hline Period & $\begin{array}{c}\text { Cumulative Average } \\
\text { Abnormal Volume }\end{array}$ & $\begin{array}{c}\text { t-Statistics for } \\
\text { Cumulative Average } \\
\text { Abnormal Volume }\end{array}$ & $\begin{array}{c}\text { Z-Statistics for } \\
\text { Positive Percentage }\end{array}$ & $\begin{array}{c}\text { Percentage Positive } \\
\text { Abnormal Volume }\end{array}$ \\
\hline$(-5,+5)$ & $5.51 \%$ & 0.60 & -0.07 & 49.78 \\
$(-5,-1)$ & $-0.26 \%$ & -0.04 & 0.33 & 51.11 \\
$(-1,+1)$ & $21.11 \%$ & $2.46^{* * *}$ & $2.20^{* *}$ & 57.33 \\
$(-3,+3)$ & $34.79 \%$ & $4.37^{* * *}$ & 1.27 & 54.22 \\
$(+1,+5)$ & $18.81 \%$ & $1.92^{* *}$ & $-3.40^{* * *}$ & 38.67 \\
\hline
\end{tabular}

* Significant at the $10 \%$ level (two-tail test)

** Significant at the $5 \%$ level (two-tail test)

$* * * \quad$ Significant at the $1 \%$ level (two-tail test)

Positive average abnormal trading volumes was observed on the pre event periods on day $\mathrm{t}=-3$ which is statistically significant at 1 percent level. After the announcement day on day $\mathrm{t}=+1$ the negative average abnormal volume is 12.82 percent ( $\mathrm{t}$-statistics $=1.42$, significant at 5 percent level). This implies the existence of overreaction on trading volume due to quarterly earnings announcements.

The cumulative average abnormal trading volumes in pre event period $(-5,-1)$ is negative 0.26 which is not significant. After the announcement day, in post event period $(+1,+5)$ positive cumulative average abnormal volumes is recorded 18.81 percent ( $\mathrm{t}$-statistics= 1.92, significant at 5 percent level) and about 38.67 percent of sample observed firm have positive abnormal trading volume which is statistically significant at 1 percent level $(z$-statistics $=-3.40)$. It means that the good-news sub-samples appear to have the higher positive abnormal trading volumes around the announcement event period. It is because of the short term overreaction to news which adjusts to the fundamental value in the longer event window. Thus, the good news sub-sample of the earnings announcements has placed the positive valuation effects around the announcement period.

Thus, this result implies that increase in earnings has statistically significant impact on the day of announcement. However, the parametric test showed significant result on day $\mathrm{t}=$ -2 , which possibly can be caused due to leakage of information. The null hypothesis in case of good-news sub-sample is not accepted as the significant signaling effect of earnings announcement is seen in the stock returns in day $\mathrm{t}=-2$. 


\section{Trading volume reaction to earnings-decrease (bad-news) announcements}

Table 5 delineates average daily abnormal volumes in panel " $\mathrm{A}$ " and cumulative average abnormal volumes in panel "B" for the bad-news announcements with respect to earnings announcement. The bad-news announcements cause strong negative average abnormal volumes, either daily or cumulatively.

The bad-news announcements cause strong negative average abnormal returns, either daily or cumulatively. On announcement day $\mathrm{t}=0$, the strong positive average abnormal trading volume of 38.50 per cent $(t$-statistic $=3.10$, significant at 1 percent level) had been reported with 62.50 percent of sample firm observed positive abnormal volume (z-statistics $=2.35$, statistical significant at 5 percent level). It implies that, on the announcement day trading volume is high among the event window which results due to short term overreaction of investors in announcement.

In pre-announcement day $\mathrm{t}=-2$ positive average abnormal volume 26.91 per cent, statistically significant at 5 per cent level ( $\mathrm{t}$-statistics $=1.75$ ) and on day $\mathrm{t}=-3$ negative average abnormal trading volume 23.43 percent, significant at 5 percent level ( $\mathrm{t}$-statistics $=$ $-1.66)$ is found. Then after, on day $t=+1$ and $t=+4$, as per the prior expectation, the average abnormal trading volume was negative 37.23 percent $(t$-statistic $=-2.15$, significant at 5 percent level) and negative 18.07 percent ( $t$-statistic $=-1.40$, significant at 10 percent level). This result, negative average abnormal trading volumes was observed after the announcement of quarterly earnings announcement under sub sample bad news.

The cumulative average abnormal trading volumes over the pre-announcement period $(-5,-1)$ was negative 12.94 percent (t-statistic $=-0.76$, not significant). Similarly, during the post-event period $(+1,+5)$, the negative cumulative average abnormal volumes was 20.26 per cent ( $\mathrm{t}$-statistic $=-1.45$, significant at 10 percent level). In overlapping period $(-1,+1)$, negative cumulative average abnormal trading volume 17.56 percent $(\mathrm{t}$-statistics= -0.98 , not significant). Thus, the bad news sub-sample of the earnings announcements has placed the negative valuation effects after the announcement period which is statistically significant. The negative cumulative average abnormal returns earned during the pre-event $(-5,-1)$ continues to be negative on the post-event period $(+1,+5)$. Hence, the negative valuation effect of earnings-decrease (bad-news) announcements on share market has been found. 
TABLE 5: Summary of average daily abnormal trading volume for the bad-news over the period 2010/11 to 2017/18:

\begin{tabular}{|c|c|c|c|c|}
\hline \multicolumn{5}{|c|}{ Panel A: Average Daily Abnormal Volume Earning Decreased Sub-Sample } \\
\hline Day & $\begin{array}{l}\text { Average Abnormal } \\
\text { Volume }\end{array}$ & $\begin{array}{l}\text { t-Statistics for Average } \\
\text { Abnormal Volume }\end{array}$ & $\begin{array}{c}\text { Z-Statistics for } \\
\text { Positive Percentage }\end{array}$ & $\begin{array}{l}\text { Percentage Positive } \\
\text { Abnormal Volume }\end{array}$ \\
\hline-5 & $-19.88 \%$ & -1.24 & -1.07 & 44.32 \\
\hline-4 & $7.97 \%$ & 0.56 & 0.85 & 54.55 \\
\hline-3 & $-23.43 \%$ & $-1.66^{* *}$ & -1.28 & 43.18 \\
\hline-2 & $26.91 \%$ & $1.75^{\star *}$ & 1.49 & 57.95 \\
\hline-1 & $-5.89 \%$ & -0.40 & -0.43 & 47.73 \\
\hline 0 & $38.50 \%$ & $3.10^{* * *}$ & $2.35^{* *}$ & 62.50 \\
\hline 1 & $-37.23 \%$ & $-2.15^{\star \star}$ & -1.28 & 43.18 \\
\hline 2 & $8.57 \%$ & 0.52 & -0.43 & 47.73 \\
\hline 3 & $12.69 \%$ & 1.03 & 0.21 & 51.14 \\
\hline 4 & $-18.07 \%$ & $-1.40^{*}$ & -0.43 & 47.73 \\
\hline 5 & $11.23 \%$ & 0.79 & 0.43 & 52.27 \\
\hline \multicolumn{5}{|c|}{ Panel B: Cumulative Average Abnormal Volume } \\
\hline Period & $\begin{array}{l}\text { Cumulative Average } \\
\text { Abnormal Volume }\end{array}$ & $\begin{array}{c}\text { t-Statistics for } \\
\text { Cumulative Average } \\
\text { Abnormal Volume }\end{array}$ & $\begin{array}{l}\text { Z-Statistics for } \\
\text { Positive Percentage }\end{array}$ & $\begin{array}{c}\text { Percentage Positive } \\
\text { Abnormal Volume }\end{array}$ \\
\hline$(-5,+5)$ & $1.37 \%$ & 0.09 & -0.43 & 47.73 \\
\hline$(-5,-1)$ & $-12.94 \%$ & -0.76 & 0.00 & 50.00 \\
\hline$(-1,+1)$ & $-17.56 \%$ & -0.98 & 1.49 & 57.95 \\
\hline$(-3,+3)$ & $2.56 \%$ & 0.19 & 0.21 & 51.14 \\
\hline$(+1,+5)$ & $-20.26 \%$ & $-1.45^{\star}$ & -1.28 & 43.18 \\
\hline
\end{tabular}

* $\quad$ Significant at the $10 \%$ level (two-tail test)

$* * \quad$ Significant at the $5 \%$ level (two-tail test)

*** Significant at the $1 \%$ level (two-tail test)

\section{Conclusion}

The study assumed that there was no significant effect of earnings announcement on stock prices and trading volumes. This is because new information contained in earnings announcements is quickly reflected in the share price thus allowing for statistically significant abnormal returns to be generated on the basis of trading only on the announcement day. The inefficient adjustment of stock prices and volume reaction to information contained in earnings announcement was found in the study.

The study also intended to analyze market's reaction to good news and bad news earnings announcements. For good news sub sample, the leakage of information was traced out from the significant abnormal returns on event day $t=-2$ and abnormal volumes on day $\mathrm{t}=-2$. It may also be the influence the market trend. This suggests that the stock markets do not respond adequately to information inflow, indicating the Nepalese stock market is not efficient in the semi-string form of market efficiency. 


\section{References}

Ariff, M., \& Finn, F. J. (1989). A: An empirical application to the Singapore equity market announcement effects and market efficiency in a thin market. Asia Pacific Journal of Management, 6(2), 243-265.

Ball, R., \& Brown, P. (1968). An empirical evaluation of accounting income numbers. Journal of Accounting Research, 159-178.

Ball, R., \& Kothari, S. P. (1991). Security returns around earnings announcements. The Accounting Review, 66(4), 718-738.

Bamber, L. S., Barron, Orie, E. B., \& Stober, T. L. (1997). Trading volume and different aspects of disagreement coincident with earnings announcements. Accounting Review, 25(4), 575-597.

Bamber, L. S., Barron, Orie, E. B, \& Stober, T. L. (1999). Differential interpretations and trading volume. Journal of Financial and Quantitative Analysis, 34(3), 369-386.

Bamber, L. S., Orie E. B, and Douglas E. S. (2011). Trading volume around earnings announcements and other financial reports: Theory, research design, empirical evidence, and directions for future research. Contemporary Accounting Research 28(2), 431-71.

Beaver, W. H. (1968). The information content of annual earnings announcement. Journal of Accounting Research, 6, 67-92.

Bernard, V. L., \& Thomas, J. K. (1990). Evidence that stock prices do not fully reflect the implications of current earnings for future earnings. Journal of Accounting and Economics, 13(4), 305-340.

Brown, L. D., \& Han, J. C. (2000). Do stock prices fully reflect the implications of current earnings for future earnings for AR1 firms? Journal of Accounting Research, $38(1)$.

Brown, P., \& Kennelly, J. W. (1972). The informational content of quarterly earnings: An extension and some further evidence. Journal of Business, 45(3), 403-415.

Dangol, J. (2008). Unanticipated political events and stock returns: An event study. Economic Review, 8(1), 86-110.

Dangol, J. (2012). Stock market efficiency in Nepal. International Journal of Multidisciplinary Research, 2(5), 40-48.

Fama, E. F. (1965). The behavior of stock-market prices. Journal of Business, 34-105.

Fama, E. F. (1970). Efficient capital markets: A review of theory and empirical work. Journal of Finance, 25(2), 383-417.

Fama, E. F. (1991). Efficient capital markets: II. The Journal of Finance, 46(5), 1575-1617. 
Foster, G. (1977). Quarterly accounting data: Time-series properties and predictiveability results. The Accounting Review, 52(1), 1-21.

Gajewski, J. F., \& Quéré, B. P. (2001). The information content of earnings and turnover announcements in France. European Accounting Review, 10(4), 679-704.

Harris, M., \& Raviv, A. (1993). Differences of opinion make a horse race. The Review of Financial Studies, 6(3), 473-506.

Jordan, R. J. (1973). An empirical investigation of the adjustment of stock prices to new quarterly earnings information. Journal of Financial and Quantitative Analysis, $8(4), 609-620$.

Kandel, E., \& Pearson, N. D. (1995). Differential interpretation of public signals and trade in speculative markets. Journal of Political Economy, 103(4), 831-872.

Kiremu, M. K., Galo, N., Wagala, A., \& Mutegi, J. K. (2013). Stock price and volumes reaction to annual earnings announcement: A case of the Nairobi securities exchange. International Journal of Business, Humanities and Technology, 3(2), 100-111.

Kong, S., \& Taghavi, M. (2006). The effect of annual earnings announcements on the Chinese stock markets. International Advances in Economic Research, 12(3), 318-326.

Louhichi, W. (2008). Adjustment of stock prices to earnings announcements: Evidence from Euronext Paris. Review of Accounting and Finance, 7(1), 102-115.

Mallikarjunappa, T. (2004). How do the Indian stock prices react to quarterly earnings? ICFAI Journal of Applied Finance, 10(3), 37-48.

Mallikarjunappa, T., \& Dsouza, J. J. (2013). A study of semi-strong form of market efficiency of Indian stock market. Amity Global Business Review, 8, 60-68.

May, R. G. (1971). The influence of quarterly earnings announcements on investor decisions as reflected in common stock price changes. Journal of Accounting Research, 9, 119-163.

Mendenhall, R. R. (1991). Evidence on the possible underweighting of earnings-related information. Journal of Accounting Research, 29(1), 170-179.

Olowe, R. A. (2011). The impact of the 2004 bank capital announcement on the Nigerian stock market. African Journal of Economic and Management Studies, 2(2), 180-201. 
Qureshi, M. A., Abdullah, A., \& Imdadullah, M. (2012). Stock prices' variability around earnings announcement Dates at Karachi stock exchange. Economics Research International, 2012, 1-6.

Rendleman, R. J., Jones, C. P., \& Henry, L. A. (1982). Empirical anomalies based on unexpected earnings and the importance of risk adjustments. Journal of Financial Economics, 10(3), 269-287.

Thomas, L. C., \& Lys, T. (1999). Post-earnings announcement drift and the dissemination of predictable information. Contemporary Accounting Research, 16(2), 305-331. 